\title{
Production and Characterization of Amylases from Zea mays Malt
}

\author{
Joana Paula Menezes Biazus ${ }^{1}$, Roberto Rodrigues de Souza ${ }^{1}$, Jesus Espinoza Márquez², \\ Telma Teixeira Franco ${ }^{3}$, José Carlos Curvelo Santana ${ }^{3}$ and Elias Basile Tambourgi ${ }^{3 *}$ \\ ${ }^{I}$ Departamento de Engenharia Química; Universidade Federal de Sergipe; São Cristóvão - SE - Brasil. \\ ${ }^{2}$ Departamento de Engenharia de Processos e Hidráulica; Universidade Autônoma Metropolitana; Iztapalapa - DF \\ - México. ${ }^{3}$ Departamento de Engenharia de Sistemas Químicos; Faculdade de Engenharia Química; Universidade \\ Estadual de Campinas; Av. Albert Einstein, 500; C. P.: 6066; 13083-970; Campinas - SP - Brasil
}

\begin{abstract}
In this work the $\alpha$ and $\beta$-amylase enzymes were obtained from maize (Zea mays) malt and were biochemistry characterized. A germination study to obtain the maize malt with good amylase activity was made. The maize seeds were germinated in laboratory and the enzymatic activity was measured daily. Activity dependence to germination time were fitted to an exponential model $\left(\boldsymbol{A}=\boldsymbol{A}_{0} e^{\mu t}\right)$, which showed that the behaviour of enzymatic activity in the germination process was similar to the growth of the microorganism. Its model could be applied to describe the mechanism of $\alpha$-amylase production for each maize varieties and others cereals. Maize malt characterization showed that $\alpha$ and $\beta$-amylase had optimal pH between 4-6.5, optimal temperature 50 and $90^{\circ} \mathrm{C}$, and molecular weight of 67.4 and $47.5 \mathrm{kDa}$, respectively. This work contributed with the advances in biotechnology generating of conditions for application of a new and of low price amylases source.
\end{abstract}

Key words: Maize seed, malting; $\alpha$ and $\beta$-amylase, biochemistry characterization, germination model

\section{INTRODUCTION}

The maize (Zea mays) is an agricultural product widely distributed in Brazil, and is commercialized natural form or with minimal processing to reduce the cost. Obtaining amylases from maize malt could add the price to the maize culture (Biazus et al., 2005a; Biazus et al., 2006; Ferreira et al., 2007). Amylases have several applications in industrial processes, essentially in the starch hydrolyse; and are used in food, pharmaceutical and textile industries (Biazus et al., 2005a; Dixon and Webb, 1971, Nirmala and Muralikrishna,
2003; Severo Júnior et al., 2007). Anybode costs U\$ 1,500/gram of purified protein (Sigma, 1996). $\alpha$-Amylase (EC 3.3.1.1) is an extracellular enzyme which is widespread among higher plants, animals and microorganisms. It catalyses the hydrolysis of the $\alpha$-D- $(\alpha-1,4)$ glucosidic linkage in starch components and related carbohydrates (Demirkan et al., 2005). It has isoelectric point of 5.4, excellent $\mathrm{pH}$ and temperature of enzymatic activity at 4.7 and $55^{\circ} \mathrm{C}$, respectively, with molecular weight varying between $50-120 \mathrm{kDa}$ (Dixon and Webb, 1971; Wiseman, 1987), but $\alpha$ amylase from finger millet malt have molecular

\footnotetext{
* Author for correspondence: eliastam@feq.unicamp.br
} 
weight between 22-26 $\mathrm{kDa}$ (Nirmala and Muralikrishna, 2003), $\alpha$-amylase from $T$. lanuginosus IISc 91 has $24 \mathrm{kDa}$ (Nguyen et al., 2000), $\alpha$-amylase from Lactobacillus manihotivorans LMG $18010^{\mathrm{T}}$, from L. plantarum L137, from L. amylovorus and L. amylophilis were of $135,230,140$ and $100 . \mathrm{kDa}$ mol, respectively (Aguilar et al., 2000). This shows that $\alpha$-amylase molecular weight is dependent from source (Aguilar et al., 2000; Biazus et al., 2005a; Dixon and Webb, 1971; Wiseman, 1987).

The $\beta$-amylase (EC 3.3.1.2) is an extracellular enzyme that hydrolyses amylopectin and glucogen, breaking each second $\alpha-1,4$ bind, but activity at leaves no reductor boundaries of the molecules. The enzyme has excellent $\mathrm{pH}$ between 4.5 and 6.5 , and $55^{\circ} \mathrm{C}$, but its inactivated at temperatures above $60^{\circ} \mathrm{C}$. Its isoelectric point is 4.8 and its molecular weight is between $20-50 \mathrm{kDa}$ (Biazus et al., 2005a; Dixon and Webb, 1971; Wiseman, 1987).

In this work $\alpha$ and $\beta$-amylase enzymes were isolated from maize (Zea mays) malt and characterized. A germination study to prepare the maize malt with good amylase activity was also conducted.

\section{MATERIALS AND METHODS}

\section{Reagents}

An Amberlite IRA 410 ion-exchange resin from VETEC (São Paulo, Brazil) was used. Maize seeds were provided by EMBRAPA, Aracaju, Sergipe, Brazil. Sodium acetate, di-nitric salicylic acid (DNS), acetic and phosphoric acids, and potassium sodium tartrate ware provided by VETEC (São Paulo, Brazil). Potassium hydrogen phosphate, disodium hydrogen phosphate, Tris, SDS, comassie brilliant blue G-250 and chlorine acid were provided by MERK (Germany). Bio-Rad electrophoresis kit was proved by BIO-RAD (Germany).

\section{Enzymes assays}

Amylase activity was assayed according to Miller's method (Miller, 1959; Nirmala and Muralikrishna, 2003) and Wohlgenuth method, called as SKB method because it was modified by Sandstedt, Kneen and Blish (Biazus et al., 2005a, 2005b; Ferreira et al., 2007; Severo Júnior et al., 2007). Twenty milliliters of $2 \%(w / v)$ soluble starch at $\mathrm{pH} 4.8(0.1 \mathrm{M}$ acetate buffer $)$ were hydrolyzed by $0.5 \mathrm{~mL}$ of enzyme sample at $30 \pm 2$ $\mathrm{C}$, for $10 \mathrm{~min}$ according to Miller method or for 1 $\mathrm{h}$ for SKB method. One unit of enzyme activity (U) was defined as $\mu \mathrm{mol}$ of glucose released per min under the assay conditions. Starch content that was dextrinized in one hour for one gram of amylase is called of SKB. DNS methos is not a specific method, it measures the activity of some hydrolytic enzymes, and however, SKB method is specific for alpha-amylase activity (Biazus et al., 2005a, 2005b, 2006; Ferreira et al., 2007; Miller, 1959; Nirmala and Muralikrishna, 2003; Severo Júnior et al., 2007). Total protein concentration was determined according to the dye binding method of Bradford (1976) with BSA as protein standard. The specific activity was calculated as activity for mass unit of protein (e.g. U/mg, $\mathrm{SKB} / \mathrm{mg}, \mathrm{U} / \mathrm{g}$ or $\mathrm{SKB} / \mathrm{g}$ ).

\section{Enzyme obtaining from maize malt}

Maize seeds were selected, weighed and washed. These seeds absorbed between 40 and $45 \%$ (w/w) of the moisture and germinated in the laboratory at room temperature and pressure $\left(27^{\circ} \mathrm{C}\right.$ and $\left.1 \mathrm{~atm}\right)$. Enzymatic activity was measured daily. The maize malt was dried at $54^{\circ} \mathrm{C}$ for $5 \mathrm{~h}$ and stored at $5^{\circ} \mathrm{C}$ (Biazus et al. 2005a, 2005b, Nirmala and Muralikrishna, 2003; Malavasi and Malavasi, 2004; Santana, 2003). Crude samples, used in expanded bed chromatography, were obtained by mixing of $2 \mathrm{~g}$ of maize malt with $0.05 \mathrm{M}$ phosphate buffers (pH 7) until $100 \mathrm{~mL}$ (Biazus et al., 2006, Santana, 2003).

\section{Enzyme characterization}

The optimum $\mathrm{pH}$ of the enzyme was determined measuring its activity, for $10 \mathrm{~min}$ in the $\mathrm{pH}$ range of 3.0-10.0 at $30^{\circ} \mathrm{C} \pm 2{ }^{\circ} \mathrm{C}$, using $5 \mathrm{~mL}$ of distilled water and $20 \mathrm{~mL}$ of a $2 \%(\mathrm{w} / \mathrm{v})$ soluble starch solution in the following buffers: $0.1 \mathrm{M}$ acetate $(\mathrm{pH}$ 3.0-5.0), $0.1 \mathrm{M}$ phosphate $(\mathrm{pH} 5.5-7.5)$ and $0.1 \mathrm{M}$ ammonium ( $\mathrm{pH} 8.0-10)$. The optimum temperature was obtained measuring its activity, for $10 \mathrm{~min}$ at temperatures between 10 and $95^{\circ} \mathrm{C} \pm 2^{\circ} \mathrm{C}$, using some soluble starch solution in $0.1 \mathrm{M}$ acetate buffer at pH 4.8 (Aguilar et al., 2000; Ben Ali et al., 2001; Duedal- Olsen et al., 2000; Mohamed 2004; Wanderley et al., 2004). Initial rates of starch hydrolysis were determined at various substrate concentrations $(0.01-20 \mathrm{mg} / \mathrm{mL})$. The kinetic constants $K_{m}$ and $V_{\max }$ were estimated by 
Lineweaver-Burk method. SDS-PAGE was performed on mini-PROTEAN II cell (Bio-Rad, USA) with $12 \%$ acrylamide gel, using buffer protein molecular weight marker (Aguilar et al., 2000; Ben Ali et al., 2001; Duedal- Olsen et al., 2000; Mohamed 2004).

\section{Amylases purification}

Expanded bed adsorption: EBA step was carried out at $22^{\circ} \mathrm{C} \pm 2{ }^{\circ} \mathrm{C}$ and $\mathrm{pH} 7.2 \mathrm{~g}$ of ion-exchange resin was used; the fixed bed height was of $4.2 \mathrm{~cm}$. Adsorbent bed was pre-equilibrated at $8 \mathrm{~cm}$ of expansion bed height, with $0.05 \mathrm{M}$ phosphate buffer at $\mathrm{pH} 7$ and flow rate of $14 \mathrm{~mL} / \mathrm{min}$. Five milliliter of maize malt crude was loaded in column bottom for promoting the adsorption of enzymes on Amberlite IRA 410 ion-exchange resin. The elution was done with $0.25 \mathrm{M} \mathrm{NaCl}$ at $14 \mathrm{~mL} / \mathrm{min}$ in descendent flux. The activity and the protein content were measured from time to time during the adsorption, washing and elution periods (Biazus et al., 2006; Kalil, 2000; Santos, 2001). Expanded bed adsorption Column: EBA column used in the present work is shown in Figure 1. The glass column was $1 \times 30 \mathrm{~cm}$ with an adjustable piston and feed flow inlet at the bottom of the column and a product flow outlet at the top. Sixty mesh plates at the feed inlet and at the product outlet were used to avoid loss of adsorbents particles. A ruler was placed at the side of the column for measurement of bed height (Biazus et al., 2006; Kalil, 2000; Santos, 2001).

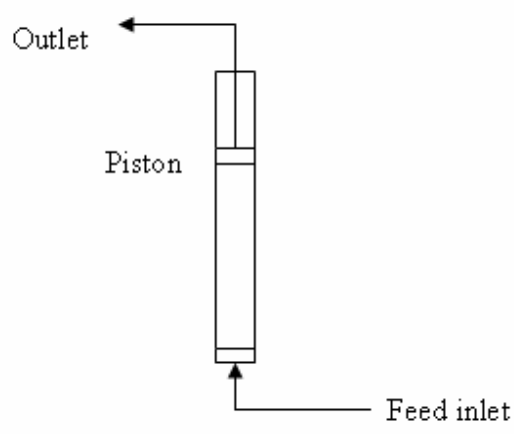

Figure 1 - Scheme of the EBA column.

Fractional precipitation: was carried out in $10 \mathrm{~mL}$ centrifuge tubes, with $\mathrm{pH}$ and temperature of precipitation medium adjusted at 7 by $0.05 \mathrm{M}$ phosphate buffer and at $20^{\circ} \mathrm{C} \pm 2^{\circ} \mathrm{C}$ by water bath, respectively. Ethanol was added to the samples purified until $50-80 \% \quad(\mathrm{v} / \mathrm{v})$ of fractional concentrations were obtained. This mixture was agitated and centrifuged at $4000 \mathrm{rpm}$ and $4{ }^{\circ} \mathrm{C}$ for 15min (Cortez and Pessoa Jr., 1999; Hilbring and Freitag, 2003). Total protein and enzymatic activity were determined in the supernatant (samples showed no precipitate) by Bradford and DNS methods.

\section{RESULTS AND DISCUSSION}

\section{Germination modeling}

Figure 2 showed that $\alpha$-amylase activity into the maize seeds in germination process was a peak curve, while the fourth day was the optimal end time. This figure showed that enzymatic activity between the methods increased until fourth day, which was the optimal germination condition. SKB method showed the presence of $\alpha$-amylase. From DNS and SKB curves showed that only $\alpha$ amylase is produced by maize seed. The decrease of activity after fourth day was due to the production of inhibithors (e.g. hydrolysis products) or due reduction of starch concentration in maize seed.

It was seen that until the fourth day the curve was an exponential function. Thus, a model based on microbial growth could be proposed $\left(y=y_{0} e^{b x}\right)$. For analogy, the following nomenclature will be used:

$\boldsymbol{A}$ and $\boldsymbol{A}_{\boldsymbol{0}}$ are enzymatic activity and initial enzymatic activity into the maize seeds $(\mathrm{U} / \mathrm{g}), \mathrm{t}$ is the germination time (day) and $\boldsymbol{\mu}$ is growth rate of enzymatic activity in the maize seeds $\left(\right.$ day $\left.^{-1}\right)$. Thus, the model could be expressed as:

$$
A=A_{0} e^{\mu t}
$$




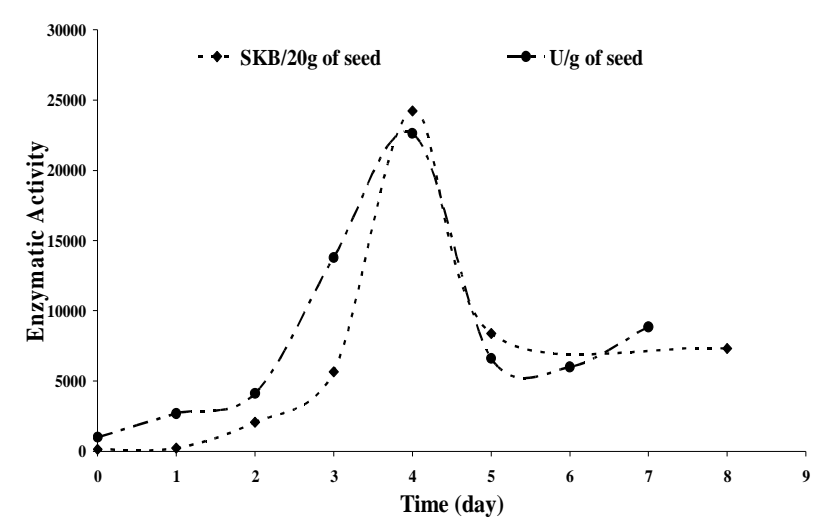

Figure 2 - Changing of alpha-amylase activity into the maize seeds in germination processes. Experimental data measured by Miller $(\bullet)$ and SKB methods $(\bullet)$.

Figure 3 shows a germination scheme of monocotyledon seeds (e.g. maize) for the best understanding this phenomenon. Germination occurs after the radix breakes up seed tegument and it shows as a young radix. The energy needed for seed germination is provided by sugar from endosperm respiration. However, the embryo and starch are separated into seed and need an action of external forces to active its physiological functions. Water absortion is the external force that breaks the dormancy of seed (Biazus et al., 2005b; Malavasi and Malavasi, 2004; Santana, 2003).

Naturally, there is a small biological activity into maize seeds due to $\beta$-amylase enzyme. This enzyme hydrolyses the seed starch for producing maltose and supplements the seed cell with energy. Until the first day, was observed a low activity (Fig. 2).

When the water is absorbed by seeds, the embryo dissolves a substance, called gyberelic acid (GA), a vegetable hormone similar to the steroids. GA is transported with water into seed tissue until the aleuronic cytoplasm, and actives DNA nuclear. This DNA is a hereditary molecule and makes all proteins that the vegetable needs to survive. Its mechanism is not known (Biazus et al., 2005b;

Santana, 2003).

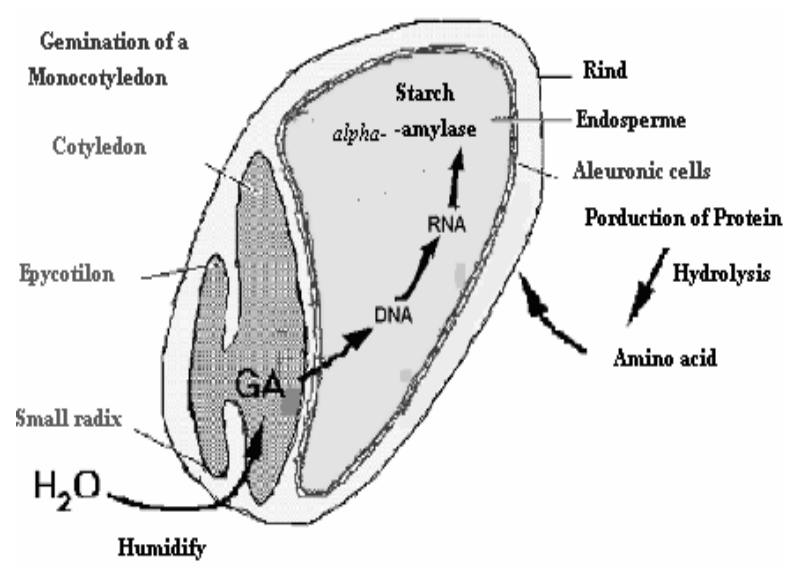

Figure 3 - Scheme of germination of a monocotyledon (maize seed). Source: Santana (2003). 
The genes are transcripts and the informations are recorded in DNA. Aleuronic cells make discard copies of this DNA, called messenger RNA. This process of coping is called transcription. RNA is transported until the cytoplasm of aleuronic cell, joining it to the ribosome for beginning the process of making a specific protein. This process is called protean synthesis or translation. In this, the ribosome examines the information from the sequence bases of RNA (Biazus et al., 2005b; Santana, 2003).

The transporter RNA stores the specific amino acids that will be put in specific positions specified in the messenger RNA and their amino acids join in sequence determined by the ribosome. The property new protein will be determined by it amino acid sequence. In this case, the critical protein making is the $\alpha$-amylase. This protein generates an enzyme of great importance for food industries. This occurred on second day until forty day; in present case, an exponential production of $\alpha$-amylase enzyme, is shown in Figure 2 (Biazus et al., 2005b; Santana, 2003).

With these data, an exponential model was fit been fitting $\left(\mathrm{R}^{2}=0.981\right)$ at $95 \%$ of confidence level, and their parameters were found as seen in Figure 4.

The $\boldsymbol{\mu}$ values were $0.7879 \mathrm{day}^{-1}$ and $1.3833 \mathrm{day}^{-1}$ and $\boldsymbol{A}_{\boldsymbol{\theta}}$ values were $1053.2 \mathrm{U} / \mathrm{g}$ and $4.576 \mathrm{SKB} / \mathrm{g}$ of maize seeds, respectively for DNS and SKB methods. Thus, the $\boldsymbol{A}_{\boldsymbol{0}}$ could be associated to the enzymatic activity of maize seeds before germination, or $\beta$-amylase activity (Malavasi and Malavasi, 2004). The parameter dependence of activity to germination time was proved by Biazus et al. (2005b) and Santana (2003). Equation 1 is a kinetic model of activity production into maize seeds. The model can be applied to describe the mechanism of $\alpha$-amylase production for each maize varieties and the $\alpha$-amylase growth in several cereal seeds.

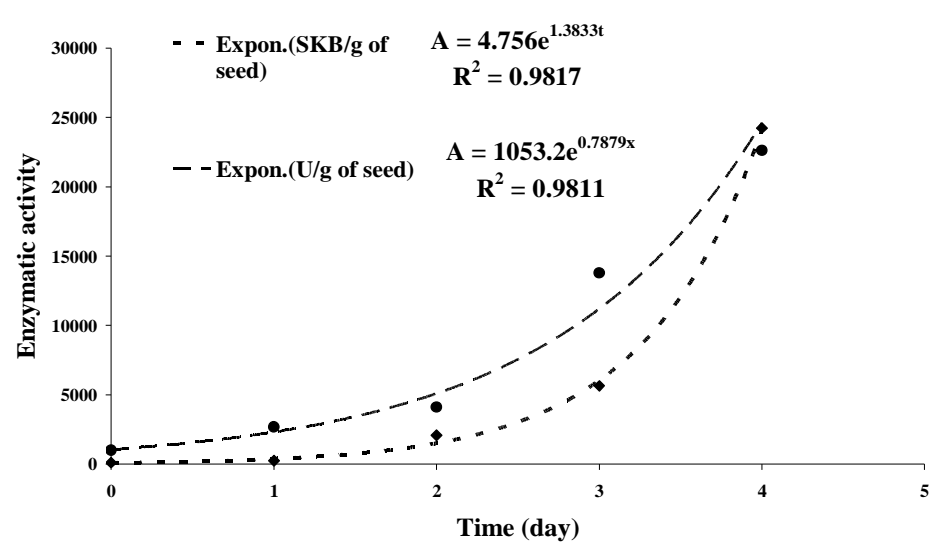

Figure 4 - Model evaluation used for simulating of increasing of the enzymatic activity of maize seeds in germination process. Experimental data measured by Milles $(\bullet)$ and SKB methods ( $\bullet$ and, (--) and (- -) are their fitting model to data, respectively.

\section{Biochemistry characterization}

Figure 5 showed that $\alpha$-amylase kept $80 \%$ of activity in a $\mathrm{pH}$ range between 4.0 and 6.5 . This was similar to the literatures reports, as the $\mathrm{pH}$ optimum of most of $\alpha$-amylase have been reported between pH 4.5-6.5 (Dixon and Webb, 1971; Mohamed, 2004; Reguly, 1996; Wanderley et al., 2004; Wiseman, 1987). However, there are $\alpha$ amylases with $\mathrm{pH}$ optimum in basic range as from Spodoptera frugiperda, S. littoralis $(\mathrm{pH} 9.6)$ and $T$. gondii ( $\mathrm{pH}$ 8.4) (Mohamed, 2004).
Figure 6 showed two peaks that indicated more than one enzyme into maize malt. It was probable that the first enzyme, at $50^{\circ} \mathrm{C}$, was the $\beta$-amylase and second enzyme, at $90^{\circ} \mathrm{C}$, was the $\alpha$-amylase, as according to the previous reports they have optimal temperature about $55^{\circ} \mathrm{C}$ and above $70^{\circ} \mathrm{C}$, respectively (Dixon and Webb, 1971; Wiseman, 1987). This thermal stability is a good factor to justify the use of this malt in industrial processes. Literatures report the optimum temperature of optimal activity at $40^{\circ} \mathrm{C}$ for $\alpha$-amylases from $\mathrm{H}$. 
bacteriophora, A. suum and S. litorallis; $50^{\circ} \mathrm{C}$ for $\alpha$-amylases from C. flavus, S. alluvius ATCC 26074, L. kononenkoae and C. antarctica CBS 667 (Wanderley et al., 2004); $65^{\circ} \mathrm{C}$ for $\alpha$-amylases from $\mathrm{T}$ gondii (Mohamedi, 2004); $55^{\circ} \mathrm{C}$ for $\alpha$ amylases from L. Manihotivorans (Aguilar et al.,
2000); and $70^{\circ} \mathrm{C}$ for $\alpha$-amylases from $\mathrm{T}$. lanuginosus (Nguyen et al., 2002). Generally, $70^{\circ} \mathrm{C}$ or higher is considerate as the optimum temperature of the most of the $\alpha$-amylases (Biazus et al., 2005; Dixon and Weeb, 1971, Wiseman, 1987; Reguly, 1996).

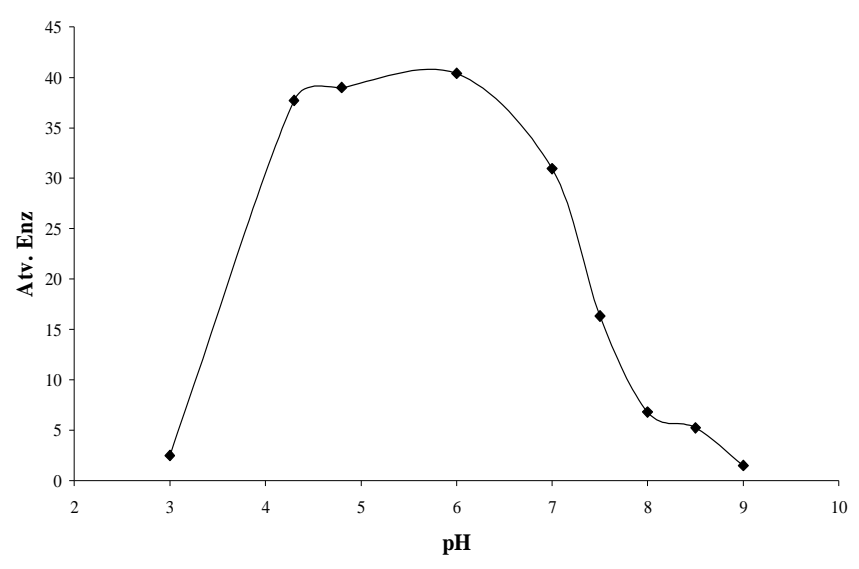

Figure $5-\mathrm{pH}$ effect on the activity of amylases from maize (Zea mays) malt.

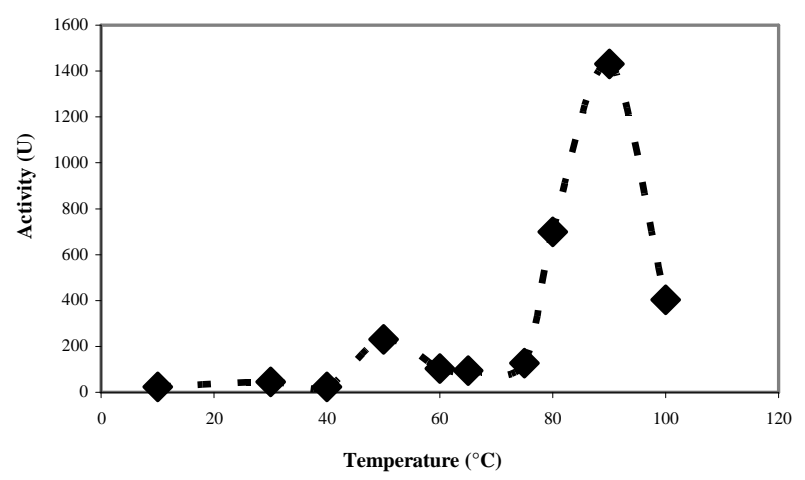

Figure 6 - Temperature effect on the activity of amylases from maize (Zea mays) malt.

By the kinetic data of starch hydrolysis by amylases from maize (Zea mays) malt, showed in Figure 7, it was possible to calculate the $K_{m}$, and $V_{\max }$ constants, by Lineweaver-burk method, equation 2 . Their values were $7.6910^{-2} \mathrm{~g} / \mathrm{L}$ and $7.6910^{2} \mathrm{~g} / \mathrm{L} . \mathrm{min}(2.48 \mathrm{U} / \mathrm{mg})$, respectively.

$K_{m}$ constant was $69-186$, which was lower than finger millet amylases (5.3-14.3 $\mathrm{g} / \mathrm{L})$ and it was lower than the $\alpha$-amylase from species of granivorous coleopterans $(0.061-0.42 \mathrm{mg} / \mathrm{mL})$ and lepidopterans $(0.037-0.38 \mathrm{mg} / \mathrm{mL})$ (Nirmala and Muralikrishna, 2003), from A. suum (0.483.33 $\mathrm{mg} / \mathrm{mL}), \quad H$ dromedarii $(10 \mathrm{mg} / \mathrm{mL}), \quad H$. bacteriophora $(6.5 \mathrm{mg} / \mathrm{mL})$ and $L$ manihotivorans (3.44 mg/mL) (Aguilar et al., 2000). $V_{\max }$ value of maize malt amylases was 2.1-2.6 greater than finger millet amylases $\left(4.76 .10^{3}-5.88 .10^{3} \mathrm{U} / \mathrm{mg}\right)$ (Aguilar et al., 2000). This value was higher than other amylases (Aguilar et al., 2000, Nirmala and Muralikrishna, 2003)). It showed that amylase from maize malt had high affinity to the starch and this factor was very important for its industrial application (Nirmala and Muralikrishna, 2003).

$V_{0}^{-1}=1 \cdot 3 \cdot 10^{-3}+1 \cdot 10^{-4}[S]^{-1}$

$(\mathrm{R}=0.9915)$ 


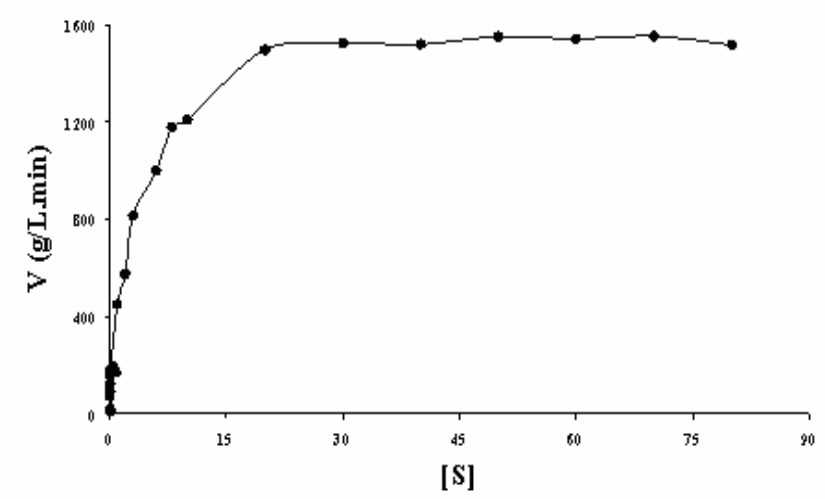

Figure 7 - Starch hydrolysis kinetic by amylases from maize (Zea mays) malt at $\mathrm{pH} 4.8$ and $30^{\circ} \mathrm{C}$.

\section{Amylases capture}

Figure 8 shows the purification of amylases from Zea mays malt by expanded bed adsorption. Analysis of this figure showed that the phosphate buffers and Amberlite IRA 410 were good medium for amylase adsorption due to lower interaction between the resin and ions from buffer. According to Biazus et al. (2006), the binding capacity of Amberlite IRA 410 ion-exchange resin at two expansion degrees ( $8 \mathrm{~cm}$ of bed height) was the best system for amylase recovery by the expanded bed chromatography in Amberlite IRA 410 ion-exchange resin. It could be associated with the presence of $\mathrm{Ca}^{2+}$ in $\alpha$-amylase and $\mathrm{Mg}^{2+}$ in $\beta$-amylase structures, given their electronegative conformations, which this enhanced their capture by resin actives sites (Biazus et al., 2006;

Dixon and Webb, 1971; Kalil, 2000; Wiseman,
1987).

In a second step, the proteins eluted from EBA process were precipitated by ethanol fractional precipitation at $\mathrm{pH} \quad 7$ and $20^{\circ} \mathrm{C} \pm 2^{\circ} \mathrm{C}$. The supernatant at $50-80 \% \quad(\mathrm{v} / \mathrm{v})$ of ethanol concentration showed that the majority of amylases were captured in liquid phase. Original medium (maize malt) contained starch and products of starch hydrolysis, which were amylase inhibitors and these inhibitors are not captured by the resin, or they were little captured and precipitated by ethanol. The activity recovery was more than $100 \%$ and the purification factor $(\sim 100)$ was better than Aguilar et al. (2000), Demirkan et al. (2005), Nguyen et al. (2002), Nirmala and Muralikrishna (2003), Santana (2003) and Zhi et al. (2005).

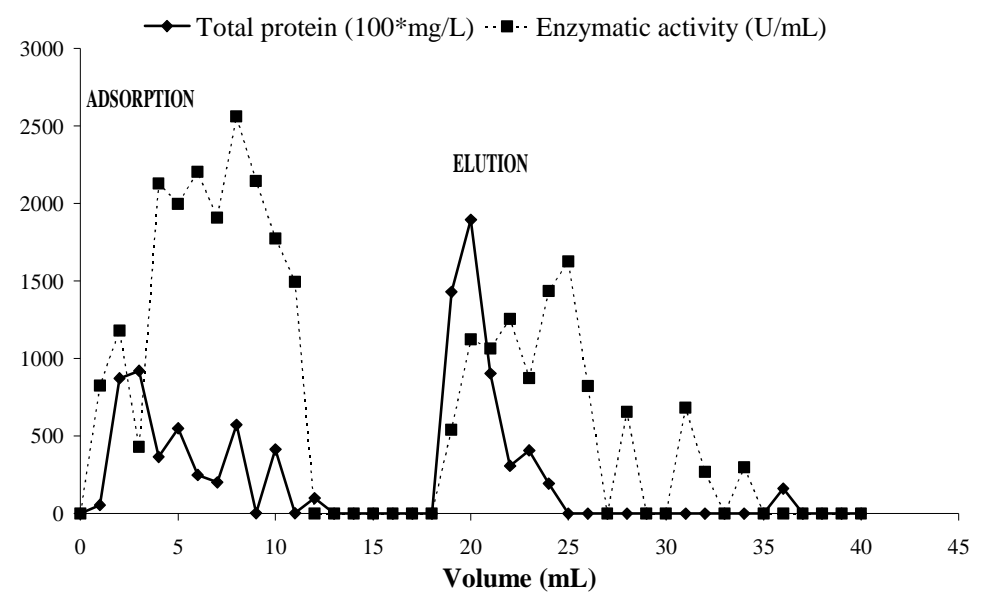

Figure 8 - Expanded bed chromatography curve of maize malt in phosphate buffer at $\mathrm{pH} 7$ and $22^{\circ} \mathrm{C}$ and with elution using a $0.25 \mathrm{M} \mathrm{NaCl}$ solution. Two expansion degree was used and fixed bed heigt was of $4.2 \mathrm{~cm}$. Total protein (- - ) and enzymatic activity (..m..). 
After EBA process the protein concentration decreased about half of initial protein concentration of maize malt crude. According to Lucarine et al. (2005), it occurred due to the resolution of fractional precipitation to be raised to the decrease of protein concentration. Amylase inhibitor also is eliminated by ethanol precipitation and increase the purification factor.

Figure 9 is SDS-PAGE analysis of the samples of maize malt crude ( $\boldsymbol{M} \boldsymbol{M})$, EBA eluted at $\mathrm{pH} 7$ $(\boldsymbol{E} \boldsymbol{E} \boldsymbol{B} \boldsymbol{A})$ and supernatant of fractional precipitation $(\boldsymbol{E P})$ of EBA eluted. This figure showed that there were adsorptions of the two proteins on the resins and that after frational precipitation, only one protein was remained.

It showed that the EBA and fractional precipitation step were very effective in amylase purification from Zea mays malt. The molecular weights in EBA eluted sample were 69.4 and $47.6 \mathrm{kDa}$, respectively, and in fractional precipitation 69.4 $\mathrm{kDa}$. It was probable that the molecular weights could be of $\alpha$ and $\beta$-amylases, as several authors have cited that molecular weight of the first enzyme, commonly, was between 50-230 kDa and of the second enzyme between 20-50 kDa (Dixon and Webb, 1971; Wiseman, 1987).

According to literature, the molecular weight is dependent of $\alpha$-amylase source; $\alpha$-amylase from Bacillus clausii (Duedal-Olsen et al., 2000) and $H$. bacteriophora $47 \mathrm{kDa}$, from A. suum $83 \mathrm{kDa}$, from $H$. dromedarii $106 \mathrm{kDa}$ (Mohamed, 2004), from $B$. stearothermophilus $59 \mathrm{kDa}$ (Ben Ali et al., 2001) and from L. manihotivoras $135 \mathrm{kDa}$ (Aguilar et al., 2000).

After fractional precipitation with ethanol, the remaining protein was $\alpha$-amylase, which was according to maize germination study that showed that enzymatic activity of $\alpha$-amylase into of maize malt was more than $\beta$-amylase. $\alpha$-amylase activity increased exponentially and $\beta$-amylase activity was constant in germination process (Biazus et al., 2005b; Santana, 2003.

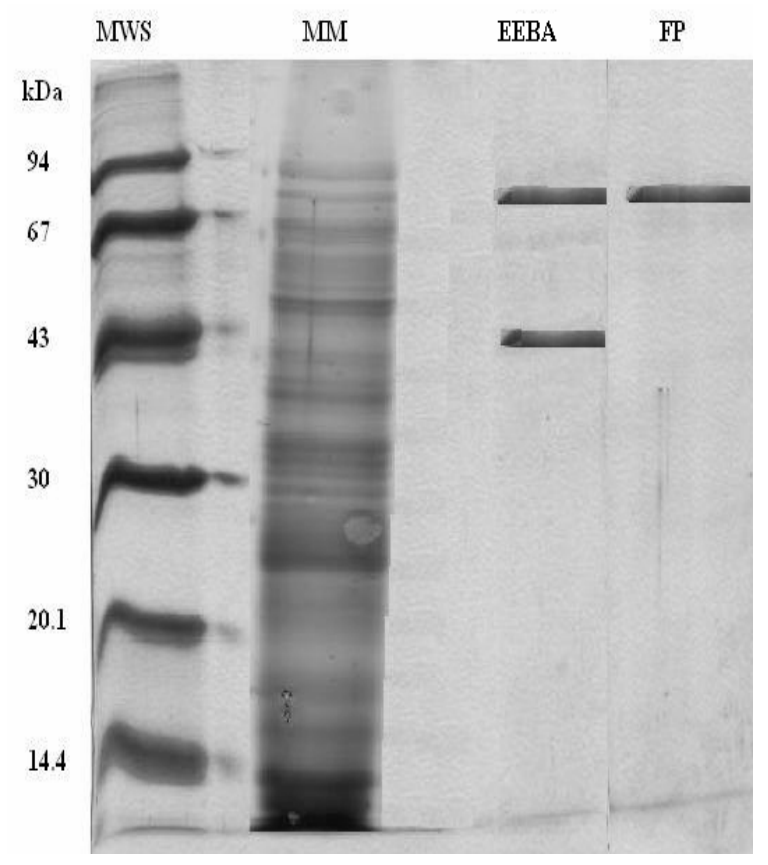

Figure 9 - Molecular weight determination by SDS-PAGE. $\boldsymbol{M W S}$ is molecular weight standard, it is compound of following proteins: phosphorylase $\mathrm{b}(94 \mathrm{kDa})$, bovine serum albumin $(67 \mathrm{kDa})$, ovalbumin $(43 \mathrm{kDa})$, carbonic anhydrase $(30 \mathrm{kDa})$, trypsin inhibitor $(20.1 \mathrm{kDa})$

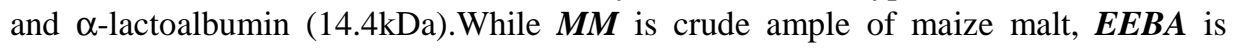
EBA eluted sample and $\boldsymbol{E P}$ is fractional precipitate sample. 


\section{CONCLUSION}

The maximum enzymatic activity in the maize seeds occured on the fourth day of germination and an exponential model, similar to microbial growth $\left(\boldsymbol{A}=\boldsymbol{A}_{0} \mathrm{e}^{\boldsymbol{\mu t}}\right)$. This model could be used applied to describe the mechanism of $\alpha$-amylase production for each maize varieties and others cereals.

Maize malt characterization showed that $\alpha$ and $\beta$ amylase had optimal $\mathrm{pH}$ between 4.0-6.5, optimal temperature 50 and $90^{\circ} \mathrm{C}$, and molecular weight 67.4 and $47.5 \mathrm{kDa}$, respectively.

This work contributed with the advances in biotechnology, showing the condition of apply an amylases isolated of a new source and of lower cost. This could add the price to maize culture.

\section{RESUMO}

Neste trabalho as enzimas $\alpha$ e $\beta$-amilases foram obtidas de malte de milho e depois foram caracterizadas bioquimicamente. Um estudo da germinação foi feito para obtenção do malte com boa atividade amilásica. A germinação ocorreu em escala laboratorial e a atividade enzimática foi medida diariamente. Um modelo exponencial do tipo $\boldsymbol{A}=\boldsymbol{A}_{0} \mathrm{e}^{\boldsymbol{\mu} t}$ foi ajustado a dependência do tempo de germinação com a atividade, mostrando que o comportamento da atividade enzimática no processo de germinação é semelhante ao crescimento de microorganismos. Este modelo pode ser aplicado para descrever o mecanismo de produção da $\alpha$-amilase para cada variedade de milho e de outros cereais. A caracterização do malte de milho mostrou que as $\alpha$ e $\beta$-amilase têm $\mathrm{pH}$ ótimo entre 4,0-6,5, temperatura ótima de 50 e $90^{\circ} \mathrm{C}$, e massa molar de 67,4 e $47,5 \mathrm{kDa}$, respectivamente. Este trabalho contribuiu com os avanços da biotecnologia gerando condições de emprego de uma nova e barata fonte de amilases.

\section{ABBREVIATION}

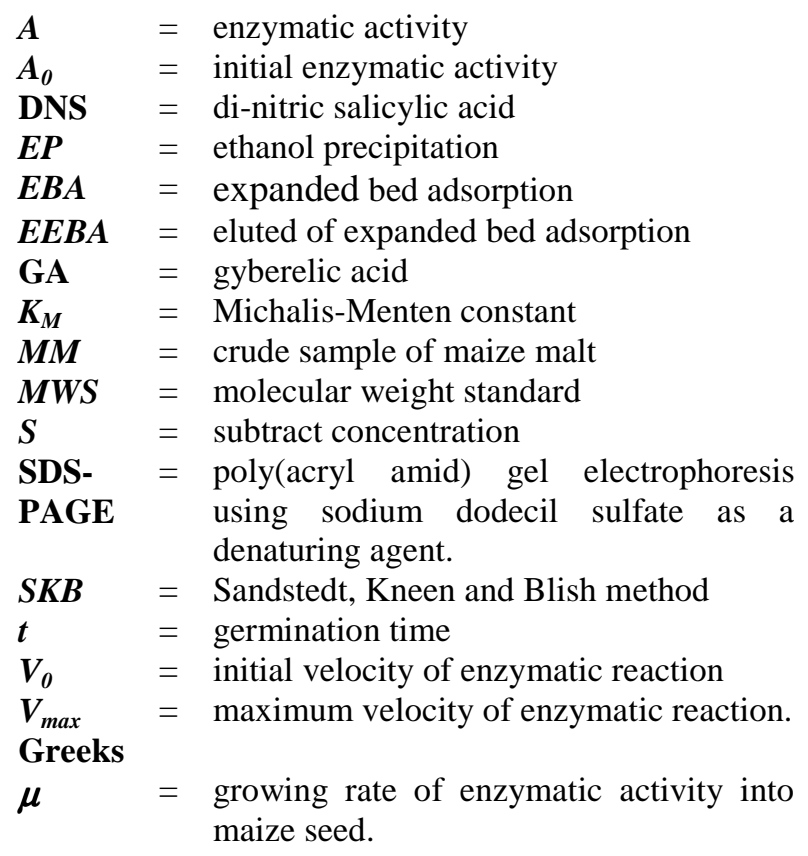

\section{ACKNOWLEDGMENTS}

The authors gratefully acknowledge the financial supports received from $\mathrm{CNPq}$, Brasilia (Brazil) and FAPESP, São Paulo (Brazil).

\section{REFERENCES}

Aguilar, G.; Morlon-Guyot, J. Trejo-Aguilar, B.; Guyot, J. P. (2000), Purification and characterization of an extracellular $\alpha$-amylase produced by Lactobacillus manihotivorans LMG $18010^{\mathrm{T}}$, an amylolytic lactic acid bacterium. Enzyme and Microbial Technology, 27, 406-413.

Ben Ali, M.; Mhiri, S.; Mezghni, M.; Bejar, S. (2001), Purification and sequence analysis of the atypical maltohexaose-forming $\alpha$-amylase of the $B$. stearothermophilus US 100. Enzyme and Microbial Technology, 28, 537-542. 
Biazus, J. P. M.; Severo Jr., J. B.; Santana, J. C. C.; Souza, R. R.; Tambourgi, E. B. (2006), Study of amylases recovery from maize malt by ion-exchange expanded bed chromatography. Process Biochemistry, 41, 1786-1791.

Biazus, J. P. M., Souza, A. G.; Santana, J. C. C.; Souza, R. R.; Tambourgi, E. B. (2005a), Optimization of drying process of Zea mays malt to use as alternative source of amylolytics enzymes. Brazilian Archives of Biology and Technology, 48, 185-190.

Biazus, J. P. M.; Santana, J. C. C.; Souza, R. R.; Tambourgi, E. B. (2005b). Maximizing of production stages of malt from Zea mays. Brazilian Journal of Food Technology, $5^{\circ}$ SIPAL, 138-145.

Bradford, M. M. (1976), A rapid and sensitive method for the quantitation of microgram quantities of protein. Utilizing the principle of protein-dye binding. Analitical Biochemistry, 72, 248-254.

Cortez, E.V. and Pessoa Jr., A. (1999), Xylanase and $\beta$ xylosidase separation by fractional precipitation. Process Biotechnology 35, 277-283.

Demirkan, E. S.; Mikami, B.; Adachi, M.; Higasa, T.; Utsumi, S. (2005), $\alpha$-Amylase from $B$. amyloliquefacies: purification, characterization, raw starch degradation and expression in E. coli. Process Biochemistry, 40, 2629-2636.

Dixon M. and Webb, E. (1971), Enzymes, Second ed., Longmans and co. 1td, London, Great Britain.

Duedahl-Olsen, L.; Kragh, K. M.; Zimmermann, A. (2000), Purification and characterization of a maltooligosaccharide-forming amylase active at high $\mathrm{pH}$ from Bacillus clausii BT-21. Carbohydrate Research 329, 97-107.

Ferreira, G. B.; Evangelista, A. F.; Severo Junior, J. B.; Souza, R. R.; Santana, J. C. C.; Tambourgi, E. B.; Jordão, E. (2007). Partitioning Optimization Of Proteins From Zea Mays Malt In ATPS PEG $6000 / \mathrm{CaCl}_{2}$. Brazilian Archives of Biology and Technology, 50 (3), 557-564.

Hilbring, F. and Freitag, R. (2003), Protein purification by affinity precipitation - Review. Journal of Chromatography B, 790, 79-90.

Kalil, S. J. (2000). Produção de inulinase por Kluyveromyces marxianus e purificação da enzima por cromatografia de troca iônica em coluna de leito expandido. PhD thesis, State University of Campinas, Campinas, SP, Brazil.

Luccarini, A.C.; Kilikian, B.V.; Pessoa Jr., A. (2005). Precipitação. In: Purificação de produtos biotecnológicos. A. Pessoa Jr. and B. V. Kilikian (eds). Vol.1. Ed. Manole, São Paulo, Brazil.

Malavasi, U. C. and Malavasi, M. M. (2004), Dormancy breaking and germination of Enterolobium contortisiliquum (Vell.) morongo seed. Brazilian Archives of Biology and Technology, 47, 6, 851-854.

Miller, G.L. (1959), Use of dinitrosalicyIic acid reagent for determination of reducing sugar. Analytical Chemistry 31 (3), 426-428.
Mohamed, M. (2004), Purification and characterization of $\alpha$-amylase from the infective juveniles of the nematode Heterorbditis bacteriophora. Comparative Biochemistry and Physiology, Part B, 139, 1-9.

Nguyen, Q. D.; Rezessy-Szabó, J.M.; Claeyssens, M.; Stals, I.; Hoschke, A. (2005), Purification and characterization of amylolitic enzymes from thermophilic fungus Thermomyces lanuginosus strain ATCC 34626. Enzyme and Microbial Technology, 31, 345-352.

Nirmala, M.; Muralikrishna, G. (2003), Three $\alpha$ amylase from malted finger millet (Ragi, Eleusine coracana, Indaf-15) - Purification and partial characterization. Phytochemistry 62, 21-23.

Reguly, J. C. (1996) Biotecnologia dos Processos Fermentativos. V. 1, Ed. UFPel, Pelotas - RS, Brazil.

Santana, J. C. C. (2003), Recuperação das enzimas $\alpha$ e $\beta$-amilases em sistema bifásico aquoso PEG/ $\mathrm{CaCl}_{2}$ para uso como biocatalizador amiláceos. MSc Thesis, School of Chemical Engineering, Campinas, SP, Brazil.

Santos, E. S. (2001), Recuperação e purificação de enzimas usando adsorção em leito expandido. $\mathrm{PhD}$ thesis, State of University of Campinas, SP, Brazil.

Severo Júnior, J. B; Oliveira, L. S. O; Sardeiro, F. S.; Souza, R. R.; Lopes, F. L. G.; Santana, J. C. C.; Tambourgi, E. B. (2007). Response Surface Methodology to Evaluation the Recovery Of Amylases By Hollow Fiber Membrane. Brazilian Archives of Biology and Technology, 50:4, 713-718.

Sigma Chemical Co., Cataloge. (1996), Biochemicals Organic Compounds and Diagnostic Reagents. 116117.

Wanderley, K. J.; Torres, F. A. G.; Moraes, L. M. P.; Ulhoa, C. J. (2004), Biochemical characterization of $\alpha$-amylase from the yeast Cryptococcus flavus. FEMS Microbial Letters, 231, 165-169.

Wiseman, A. (1987), Handbook of Enzyme Biotechnology, second ed., John Wiley Sons, New York, EUA.

Zhi, W.; Song, J. Ouyang, F.; Bi, J. (2005), Application of response surface methodology to the modeling of $\alpha$-amylase purification by aqueous two-phase systems. Journal of Biotechnology, 106, 157-165.

Received: May 25, 2006; Revised: March 22, 2007; Accepted: September 09, 2008 